\title{
14 Older adults' religiosity during the COVID-19 pandemic
}

\author{
Catholic Church in action
}

\author{
Bolestaw Karcz
}

Diseases of all kinds, especially contagious ones that destroyed societies, mobilized the Church community to help. This is what happened in the present situation. The Church has not forgotten her faithful; he met them in a difficult social situation. The pandemic changed the possibility of religious engagement, both personal and family and social, of seniors. They were not able to participate directly in the Holy Mass, receive Communion and other sacraments. They also had to change the routines of spiritual and religious life. Virtual reality had to replace the real one, but the Catholic Church has always tried to stay close to society. The ministry had to be implemented in a virtual formula. Nevertheless, various ideas for pastoral care in a pandemic situation on the part of the Church were used. The activity of the Catholic Church has become the basis for the implementation of the new evangelization based on virtual activity, and the Church has joined in this narrative and activity within the framework of the propagated social principles of the Church: the principles of the common good, the principles of solidarity and subsidiarity. This chapter presents the activities of the Catholic Church in the face of the COVID-19 pandemic and spiritual help for the elderly at risk of this virus.

\section{Religiousness of older adults}

On the basis of social cohesion research, the Central Statistical Office developed an indicator of religious commitment based on declarations regarding attitudes, activity, religious beliefs, as well as the sense of belonging to a religion or religious institutions. It was about the sense of belonging to the Church, community or religious organization, manifested in membership and shared responsibility, as well as devoting time to community work within this community and the frequency of performing this work; attendance at events or activities organized by that organization, community (and the frequency with which it occurs); membership of the Church or religious 
association. The self-declaration of faith was also taken into account attitude to religious faith, religious practices assessed as the frequency of participation in holy masses, services or religious meetings, the frequency of prayers, sense of connection with a parish, church, local church, own religious community, and finally the importance of religious faith as a value in life. The older adults are clearly characterized by the highest level of religiosity. This mainly affects people aged 75 and over, but also people aged 65-74. Among people aged 75 and over, more than half (approx. 51\%) are people with at least an average level of religious commitment, including the fact that over $10 \%$ was included in the very committed group. The group of the oldest people is also characterized by the lowest share of people not religiously involved and not related to any religion (18\% in total). Among people aged 65-74, the total percentage of people who were not religiously involved and not related to any religion amounted to $28 \%$, while people who were moderately or very religiously committed to about $41 \%$, including very committed - almost 8\% (Główny Urząd Statystyczny 2018: 1-6). It is true that this is a study for 2015-2018, as there are no current data for the last two years, but the level of religiosity is probably similar, although it definitely took a different form during the pandemic. However, it is important, that older adults are the largest group involved in religious practices.

To better define the essence of religiosity, we must look at its definition. PWN (State Scientific Publisher) defines religiosity as:

- in Christian theology, the moral virtue consisting in showing God due honor through internal worship (adoration, trust, love), as well as through external worship (sacraments, prayer, asceticism);

- in psychology and sociology of religion, the attitude of a person or a social group towards dogmas, orders and religious customs in force in a given religion, which is manifested through the assimilation of these principles, their acceptance and compliance with them; research on religiosity is empirical in nature and uses research techniques typical of psychology and sociology.

And although religion itself eludes empirical research, it should be stated that what can be observed is the fact that religion influences people and entire communities. This also cannot be investigated directly but through the religious acts of a specific individual. People's involvement in various forms of worship, meditation on God, talking to him in prayer, deepening religious knowledge and conforming to ethical standards resulting from religion and acting in a spirit of love for one's neighbour - this is what we call religiosity (Adamski 2011).

In the context of a pandemic, individual faith and religiosity take on new meaning. Shocking events, enormous experiences of losses, a feeling of helplessness in the face of the power of COVID-19, forces that are not dependent on man, create a huge spiritual emptiness. The most important questions 
are asked: about the meaning of life, illness, death, about what is most important in life. They can transform the entire thinking system of mankind. The epidemic that is lived through, as an invisible force with a mysterious effect, but bringing death to many thousands of people, becomes a challenge for the spiritual and religious life of everyone who lives it.

The coronavirus crisis may become a wake-up call in times when the perceptions related to temporality dominate. Many people think of various paradises on earth where our human longings can come true - these are paradises: huge financial resources, leisure, travel into the unknown, countless shopping, extreme sports, for which people work hard just to get these "material paradises." Today it is necessary to go beyond these temporal-centered images to come to a true and complete understanding of humanity. This may become possible when we break these worldly visions and open ourselves to the perspective of heaven. This paradise belongs to God, but the way to it is made through a creative life for others, resignation from self-centeredness, avoiding self-destructive actions and destroying the bonds and living bases of others (Augustin 2020: 90-91). George Augustin read perfectly on the ethical and spiritual level, the abbreviation COVID (Corona Virus Disease) encoded in our memory by the epidemic. He proposes that we read it as follows:

C-confidence (trust God)

$\mathrm{O}$ - opportunities (take advantage of opportunities)

$\mathrm{V}$ - values (rediscover essential values)

I - intelligence (to discern spirits in wisdom)

$\mathrm{D}$ - dedication (give a gift to God by committing yourself to people and the world)

It can be said that this is a spiritual and ethical program for everyone in the current pandemic (Augustin 2020).

For the purposes of this study, the above abbreviation COVID, proposed by the theologian Georg Augustin, was adopted in order to recognize the religiosity of older adults in the current situation.

C: confidence read as trust in God becomes the basis of religious life. The Church therefore calls for the experience of the pandemic to be interpreted as God's "signs of the times." It is significant that the time of the coronavirus crisis appeared shortly after the beginning of Lent. Many of the faithful interpreted this sign as a kind of extension and continuation of the mystery of Holy Saturday. In the Christian liturgy, it is a reflection on the day of the mystery of God's burying, His hiding and silence in human history, therefore it is also the day of the feeling of human hopelessness. This Holy Saturday of 2020, during the pandemic, has become a symbol of the difficult life situation of mankind - a symbol of the enormity of fears for one's own and loved ones' lives, fears for the future and the constantly asked question: when will the current crisis end and what will life after it look like (Koch 2020). 
In view of the great unknown about the future, a question arises as to how to read this crisis and how to react to it. Should this experience be accepted as naturally occurring from time to time in history? Should we trust only on the experience of scientists and wait for a scientific-medical solution? Or should it also be read in the context of faith - trust in God? Christianity can reconcile all currents in the perspective of the "signs of the times" that God gives to live this time spiritually - reflecting on the appreciation of the gift of life, being a child of God, the transience of the world, looking at earthly life as a transitional place to live with God in eternity, the discovery of the family bond and the general human community. This is the time to trust God. This trust is justified by the fact that the Holy Scriptures, with all their respect for nature, place great hope in God's grace and therefore constantly invoke their help in prayer, in the conviction that the deepest essence of prayer is the call of SOS, i.e., a call for help in the original meaning of this abbreviation: Save our Souls... Such trust in God's grace does not interfere with taking seriously the recommendations of experts who know the secrets of nature, which God created (Koch 2020). Older adults who have a lot of experience in life and those who experience its decline are more sensitive to transcendence and an eschatological view. They experience the trust of God's Providence more deeply, hence their prayer commitment - a conversation with a loving Father who takes care of his children and shows that "our homeland is in heaven".

\section{O: opportunities is the use of opportunities}

The Pontifical Council for the Laity in the document entitled The dignity and mission of the elderly in the Church pointed out that the pastoral care of people of the third and fourth age should make it easier for elderly people to participate in the celebration of the Eucharist, to enjoy the sacrament of reconciliation, to participate in pilgrimages, retreats and days of recollection. Elderly people should also be accompanied spiritually. They should be given the opportunity to receive the Anointing of the Sick and Viaticum. As older people make up a large percentage of media audiences, especially as radio listeners, TV viewers and readers, it is important to ensure that programs and publications are particularly suited to them, so that they offer them not only material for relaxation and recreation, but also an aid to the ongoing formation that is desirable in all ages (Dziedzic 2015: 102).

In this difficult pandemic time, the availability of the holy sacraments changed dramatically, especially to the Sunday or holiday Eucharist and to the sacrament of penance. The Holy Father Francis and the Episcopates of individual countries have made unprecedented decisions to limit the faithful participating in Holy Masses, and in some countries even completely cancelled them. It was dictated by the concern to limit the spread of the C-19 virus in the name of the most important commandment of love of God and neighbour. 
Instead of actually attending Mass, many parishes have introduced Internet transmissions from their churches so that the faithful can unite in the prayer of the church community. Statistics showed that this kind of participation enjoyed the greatest participation of the absent participants of the Mass liturgy. Likewise frequent radio and television broadcasts. During this time, the faithful were introduced to such content as perfect repentance for sins and spiritual Holy Communion, which so far had been used by people living in non-sacramental relationships, i.e., those who could not receive sacramental absolution under ordinary conditions and receive Christ's Body (Ziębińska 2010).

Numerous communities of the Church introduced evangelization content in interesting forms of expression into virtual reality and social media. Little-visited websites of individual parishes so far became a place of very active contact with parishioners, where information about the latest parish life and initiatives was provided. Many people who had not taken much religious participation so far have made virtual contact with priests. Paradoxically,

it was during the period of social distance, isolation and quarantine that pastoral ministry developed in the virtual space, and the Church strengthened despite the lack of access to the sacraments of believers and the experience of a community physically gathered in the same place.

(Skworc 2020: 6)

A very significant element of contact was telephone conversations with priests of a pastoral nature and organization of charity aid for the older people suffering from disease, quarantine and isolation.

V: values reads as rediscovering relevant values. Many people today ask themselves: Why do we have to deal with this type of crisis? But such a question will not take us too far. Rather, you have to ask yourself: What is this crisis for? It is up to each person what to learn from this difficult experience, what conclusions they draw and what they will do to contribute to a better personal and social life. The experience of the pandemic makes us realize that the question of life, the problem of noticing conditio humana in all its splendour and poverty, remains constantly relevant. It is the mystery of life that we can consider from different sides. We are even more aware that our earthly and biological life is limited, which gives rise to another reflection on the meaning of death and the transition to eternal life. It is a way to appreciate the value of life as a gift from God. In the biblical sense, life is directed towards God and towards communion with Him. It is life in God and with God that is realized in living with others. All life takes place in the living presence of God: in the arising, in becoming and sustaining of a single life, as well as in its limitation through death, and in the hope of a living community that transcends this death (Augustin 2020). 
The virus made us very brutally aware of human fragility and transience, as we realized even more clearly that we are mortal - threatened by a deadly disease that consumes thousands of people a day. Thus, death makes us aware of the mystery of life, which was very accurately expressed by St. Augustine, experiencing the pain of the death of his friend: "And I became a big question to myself" (Augustin 2020: 77), and

When we perceive our life as a gift, then God in Christ appears to us as a Giver... As a creature, I can trust that even after earthly life does not cease to fellowship with Him, which in itself is life.

(Augustin 2020: 83).

The value of life as a whole, i.e., earthly and eternal life, is the supreme value in times of crisis:

Faith, therefore, illuminates the mystery of death and illuminates with its light old age, which is no longer perceived and lived as a passive waiting for the moment of annihilation, but as a harbinger of the imminent achievement of full maturity. These years should be lived in an attitude of trusting entrustment to God, to a generous and merciful Father; this time should be used creatively, striving to deepen the spiritual life through more intense prayer and zealous service to brothers in love.

(John Paul II, pt 16)

The second value is the experience of a family community. Already in the pages of the New Testament, the Christian family is presented as the domestic church. The Acts of the Apostles describes the first converted families and homes that became communities of worship, mission, and Christian help, and St. Paul describes communities of believers, i.e., the Church, assembling at the house of Aquila and Priscilla [cf. 1 Cor 16,19; Rom 16,5], Philemon in Colossi [Philem 2], Nymphs [Col 4,15], as well as Gaius [Rom $16,23]$. In the 1st centuries of Christianity, there were as yet no special places of God's worship, and believers in Christ flocked to ordinary houses. It was the family home that was the place of prayer, singing psalms, and most of all celebrating the Eucharist, and the place where attitudes of Christian help were shaped. St. John Chrysostom, who lived in the 3rd century, was the first who called the family a little church, where the liturgy was celebrated, the texts of the Bible were considered, the truths of faith were taught, and alms were organized for the sick and the poor. He had a similar understanding of the family to St. Augustine. Following this idea, the Second Vatican Council called the family "home Church" [LG 11], where the faith is first transmitted through mutual love and common prayer, the family joins the liturgical worship of the Church and is a place where virtues are practiced and good works are performed (Przygoda 2020). 
While the pandemic limited participation in services in churches and places of worship, it did help many families to understand better the essence of the domestic church, common prayer and the organization of help for others in the Christian spirit.

So far, in the efforts of parents who want to provide the best possible life for their children and the whole family, there has often been no time for themselves, for common conversations, and for their interest in children's experiences - their passions, progress in school education, sharing the time of adolescence, first infatuations and discovering love, puberty and making serious decisions about the future. The time of pandemic isolation forced to some extent to spend time together with the family. Many parents, as well as children and adolescents, worked and studied remotely at home, spent a lot of time with each other, having the opportunity to talk, get to know each other better and appreciate the gift of the family community. In many houses, people gathered together to experience the Sunday Eucharist through broadcasts or to participate in other services online. Many families have rediscovered the power of daily family prayer. The family, rediscovered in its essence, as a community of life and love [GS 48], is able to satisfy the need for care, friendship and security (Przygoda 2020).

The third value is the perception of older adults in family and social life. It is in the family community that the presence of older adults plays a huge role. Nowadays, when older people are perceived as "superfluous people", it is even more important to note that many people are reaching old age. Even today, young people or middle-aged people should remember this. In his Letter to my brothers and sisters - older people, John Paul II drew attention to the immensely important role played by older adults in society:

We all know old people who can be an eloquent example of amazing youth and vitality of spirit. Those who come into contact with them are able to use words to stimulate action, encouraging them by their own example. May society fully appreciate the old people who, in certain parts of the world... are rightly honoured as "living libraries" of wisdom, guardians of the priceless human and spiritual heritage. While it is true that in the physical dimension they usually need help, it is also true that even in old age they can be a support for young people who take their first steps in life and seek their own way.

(John Paul II, pt 12)

The role of older adults in families and communities in the era of the coronavirus has become even more important. In many homes, children learning remotely are looked after by grandparents who help their parents by raising the young generation. They look after them, talk to them, help them learn, and shape their spiritual life through common prayer or participation in catechesis, Holy Masses and online services. It is one of the manifestations 
of religiosity, that is, the external expression of faith, bearing witness to Christian life and evangelizing the families.

However, it should be remembered that the family also has its Christian duty towards older adults, which was emphasized by John Paul II: "Before you go gray, you will respect the face of the old man" [Lev 19, 32]. To honour old people means to fulfil a threefold duty to them: to accept their presence, help them, and appreciate their virtues. In many environments it is a natural way of proceeding, in line with the ancient custom. Elsewhere, especially in the more economically developed countries, it is necessary to reverse the current trend, so that the older can age with dignity without fear of losing relevance. We must realize that a truly human civilization is characterized by respect and love for old people, thanks to which they can feel - despite their weakening strength - they are a living part of society. Cicero wrote that "the burden of years is lighter for those who feel respected and loved by young people" (John Paul II, p. 12).

The fourth value is appreciation of the church as a place of worship, a parish and the role of the clergy in society. Many believers suffer very badly from the lack of direct participation in the Church's liturgy due to the state authorities limiting the number of the faithful in Holy Masses and church services, and limited opportunities to use the sacrament of reconciliation and anointing of the sick. This particularly affects the sick and the older people staying in hospitals or nursing homes. It was also necessary to reform the preparation of children for the First Holy Communion and confession, as well as the formation of young people preparing to receive the sacrament of Confirmation. In many parishes, these ceremonies were postponed, and in other cases, these sacraments were administered in small groups to conform to epidemiological recommendations. It was similar with the preparation of the engaged couple for the sacrament of marriage and the conclusion of this sacrament by them. In the present situation, the possibility of participating in pastoral groups at parishes as well as direct contact with clergy has been limited. Many parishioners express deep pain and sadness at the inability to use the pastoral offers they have participated in and direct conversations with priests (Lipiec 2020).

The fifth value is the Church's chance to open up to those seeking a spiritual path and change of life. Many people who do not identify with the community of the Church and its teachings, lost in the COVID chaos, are looking for answers to the bothering questions about the meaning of life, suffering and death. These searches are most often made in the virtual space, which the Church uses more and more often in its mission. These are contacts by e-mail or on social media and forums directed to parishes, pastoral groups, individual priests or believers, who give testimony of their faith in this space. The Second Vatican Council indicated three ways to open up dialogue: with other Christian Churches, with non-Christian religions and with "non-believers". The Czech theologian Tomas Halik describes the third group as Noni. They include people who do not want to be counted 
among the followers of any existing religion. Noni are not atheists who reject the possibility of God and a spiritual reality, but are a very diverse group, i.e., apateists (religiously indifferent), agnostics, anti-clericals, followers of different spirituality, syncretists, people disappointed or hurt by religious institutions and people who sincerely seek spiritual reality. He considers them a great task in the third way of dialogue, which he calls the third ecumen. In the future, the Church, apart from the traditional pastoral care of believers who belong to parishes or formation groups, will face a new task in addition to missionary activity focused on acquiring new members, that is seeking spiritual accompaniment, which already takes place in hospitals or prisons, where the service of spiritual support, consolation, and various conversations covers all those in need and is not focused on conversion in the ecclesial and religious sense. Nevertheless, conversion in the sense of metanoia is also at the centre of this ministry - a change of life, which Heidegger understood philosophically as Khere (a turn) - a departure from an inauthentic life in constant pursuit of only temporal needs, where you live like everyone else (Heideggerian "oneself," "one lives") to a real life based on the voice of conscience (Halik 2020: 131-152). Thus, the time of the pandemic presents the Church with new tasks.

\section{I: intelligence - to discern spirits in wisdom}

Holy Father Francis on March 27, 2020 in the empty St. Peter, while praying for an end to the pandemic, delivered a very moving homily in which he stated:

Thick darkness has gathered on our squares, streets and cities. They engulfed our lives, filling everything with a deafening silence and a gloomy void that paralyzes everything in its path. You can feel them in the air, notice them in their gestures, your eyes tell about it. We got scared and lost.

(Francis 2021 - online document)

The pandemic has caused an acute fear that takes various forms, that is fear of infection, illness, death of loved ones, economic collapse of unemployment, bankruptcy and lack of development prospects, as well as fear of loneliness, loss of meaning in life and death. There is also doubt in God's Providence and fears about the future of the world. It also causes a natural fear, which is a spontaneous human reaction to the perceived danger. Nevertheless, in the midst of this chaos, there is the dangerous phenomenon of artificial fear inducement generated by the modern prophets of pessimism, the apocalyptic end of the world, and the supposed "hours of punishing God" (Nota Komisji Nauki Wiary 2020: 45). The basic mistake of these false prophets is to express themselves incorrectly and at the same time suggestively on behalf of God, giving erroneous ideas for solving a pandemic 
situation, falsified description of God's providence, which intervenes according to human ideas. This approach results in despair - a sense of hopelessness that leads to doubt and lack of faith in overcoming the threat.

It is wrong and dangerous to obsessively look for the person or groups of people who are responsible for the pandemic by condemning, stigmatizing and blaming them. Equally harmful is the presentation of a distorted historiosophy, invoking false revelations and dreams, misinterpreting biblical texts, as well as questioning contemporary Church teaching, e.g., on the order of nature and grace, the spiritual and material dimensions, which lead to the neglect of safety during the liturgy (Nota Komisji Nauki Wiary 2020).

We also cannot treat magically the sacraments and sacramentals or portray the Church as a "safe ark" that is reserved only for those attending Masses and services held in churches by reciting God's grace to those faithful who unite in the prayers of the church community through the mass media.

Particularly dangerous is the phenomenon of the creating and activity of pseudo-religious sects or groups using human fear related to COVID-19. The time of pandemic, anxiety, fear, isolation and death of loved ones causes depression states to many people who are subject to various types of confabulations and manipulations. It is used by some sects or so-called gurus who prey on people scared by the coronavirus, especially the older and the sick people, separated from their loved ones. Often, they are willing to give up their possessions, such as savings and even housing, to receive a false hope of survival. Since the coronavirus emerged, pseudo-religious groups have been attracting increasingly older people, terrified of the inevitable end of the world as we know it. At the present time, the issue of health is becoming a sensitive issue, and therefore extremely delicate. Be careful... Older people can be manipulated by some group, some self-proclaimed guru, by someone who will come and say that some particular therapy will help solve all problems (https://www.polskieradio.pl/9/325/Artykul/2626431,UwagaKoronawirus-sprzyja-sektom - 27.01.2021).

An example of such activity is the sect Science about Happiness spreading around the world (Japanese Kofuku no Kagaku). It was founded in 1991 in Tokyo by Ryoho Okawe and now finds its followers in Japan, USA, Uganda, Russia and Bulgaria. The sect's offer includes "effective exorcisms against C-19," and Okawa presents himself as having a special relationship with $E l$ Cantara, which is "Higher Spiritual Being" and "Higher Consciousness." El Cantara is the only spiritual being (depicted in the form of an angel with a white dove at his feet sending rays of grace) who combined the values of four religions: Islam, Christianity, Buddhism and Confucianism in order to obtain miracles, healings, deliverance from evil and provide happiness in life. In the temple of this sect in New York, there is distributed the book titled: Spiritual readings on infection with the new strain of the coronavirus originated in China. Okawa calls for faith in El Cantara, assuring that only he can eradicate the C-19 virus. Sect stores sell "exorcisms and blessings" for 
\$100-\$ 400. According to Okawa, the C-19 virus is a biological weapon that has eluded the Chinese supernaturally and turned against the communist, godless Chinese, as well as anywhere in the world where there is no "real faith" (Zwoliński 2020).

Also in South Korea, the apocalyptic sect of Sincheonji (Church of Jesus Christ of Heaven and Earth) founded in 1984 by Li Man Ki, who describes himself as the immortal incarnation of Jesus. Sect leaders forbade their members to follow the hygienic regime during a pandemic by wearing face masks and keeping people distant during collective services. They argued this with "God's wrath" that would reach anyone who did not follow the sect's recommendations, and the refusal to participate in the rites was unacceptable. Li Man Ki said that if you betray our church, you become a dog and a pig; you lose your right to salvation. He also called the C-19 "the devil's act" to discourage people from joining the ranks of Sincheonja. The authorities surveyed over 210,000 members of the sect. Some of them refused to do the tests. The Korean public filed a petition to ban the sect and collected over 1,250 signatures of the citizens. South Korean authorities have brought charges against the guru of this sect regarding, among other things, murder, injury and violation of state laws regarding epidemiological control. Over $60 \%$ of 7,500 people infected C-19 in Korea are Sincheonji followers. The sect has become one of the sources of the epidemic in this country. The sect operates in South Korea, the USA, China, India, New Zealand, Australia, as well as in some European countries, such as England (https://forsal.pl/ artykuly/1460145,1e-monde-epidemia-covid-19-zdemaskowaladzialalnosc-sekty-shincheonji-z-korei-pld.html - 27.01.2021).

In Poland, a sect called New Covenant Church in Lublin propagates various false information about the pandemic. According to them, C-19 is a product of the Chinese Communist Party and Poland still belongs to the communist bloc due to the pandemic. They call the coronavirus a "biological weapon" as well as the "virus of the Chinese Communist Party." They believe that the sect suffered losses by not being able to meet in public, and many of them had to go into quarantine, which contributed to financial and moral losses. The leader of the sect - Paweł Chojecki - founded an independent television called Go against the current, which presents only absurd theories about the virus, preached by the leader. Sect members and viewers of this television are urged not to watch any other information on the subject. There was created a system of mutual observation within the sect, and warnings against making friends and making new acquaintances. There was also organized an action called, which threatened the health and safety of Polish society, and Poles were threatened that all protective measures imported from China were deliberately infected with coronavirus. In his theses, Chojecki also refers to biblical texts, which he interprets as he pleases, bending them to his own false theories (Ziębińska 2010: 285-286).

There are many such sects and pseudo-religious groups in the world. They take advantage of the fear and anxiety caused by the pandemic. So you need 
to be very careful not to succumb to this type of manipulation. Therefore, the Church teaches to discern spirits in wisdom, because "mature religiosity requires human cooperation with God, combining human activities with openness to the gift of God's grace, reliable knowledge with deep faith, daily activity with fervent prayer" (Nota Komisji Nauki Wiary 2020: 47).

D: dedication is to give a gift to God by committing yourself to people and the world. The pandemic drew our attention to mutual love even more. Love for our neighbour is the most important distinguishing feature of biblical ethics. It can even be said that it has become a heritage of world culture. Mentioned in the Old Testament in Leviticus [Lev 19,18] (World English Bible), it was defined by Jesus as the most important commandment [Mark 12,28-34] (World English Bible), while the parable of the Good Samaritan became an image of mercy towards others, extending them beyond the boundaries of Christianity:

the love of neighbour is an ethics that puts the other in front of us, within our sight. It is not condescending but humble, not disrespectful but empathetic. It does not reach far away, but remains close to us, moving and touching. It is a matter of the heart - or it is not love of neighbour.

(Söding 2020: 100)

The commandment of love applies not only to the person of one's neighbour, but it strengthens those who follow it in three ways. First of all, it says: You love, so it is about personal commitment and not for someone else to do it. The second thing is to love your neighbour, that is, not anyone, but someone who lives in our world. This is a dimension of our responsible treatment of other people. And the third thing is that we should "love our neighbour as ourselves" - not selfishly, but also not as part of self-destruction. It is about shaping your humanity by finding fulfilment in helping others (Söding 2020: 106).

The Church over the centuries, using its own capabilities, in the face of the lack of state organizations at that time until the modern times, built its own hospitals (shelters for the care of infected and seriously ill people). They served to care for the sick and isolate them, thus protecting others as well as enable pastoral care for patients and residents. Similarly today, church charities, incl. Caritas, Misereor, Adveniat, Missio, Renovabis help those in need all over the world, regardless of religion, skin colour or belief. In this way, the Church supports sustainable development, reduces risk and prevents social marginalization. The Church also has a duty to follow the rules of social distancing that are dictated by state authorities, based on the recommendations of medical experts, and strongly recommend them to be followed. It is inscribed in the most important commandment - love of God and neighbour (Söding 2020: 119).

During the pandemic, numerous initiatives for older adults also play a very important role: "Therefore, all social initiatives, thanks to which the older can not only take care of their physical and intellectual condition and 
develop relationships with others, but also become useful by giving others their time, skills and experience, deserve recognition" (John Paul II: 16). An important form of activity of older adults are various forms of education, currently mainly on-line. It can be carried out in various institutions - both organized (e.g. schools, universities, courses), and in informal institutions through contact with the press, radio, television or the Internet (GagatMatuła \& Myśliwiec 2011). The rapidly developing universities of the third age also play an important formative and educational role. It is a new quality in the area of lifelong learning and intellectual and psychophysical activity (Ilnicka 2006). These institutions not only help retirees to organize their free time, but also often influence their spiritual development (Dziedzic 2014).

The third age is the stage in life that should be used to engage in supporting others (Lipiec 2020). Despite good health, these people sometimes have no motivation to engage in such pro-social activities. Therefore, those movements and organizations that help the older to abandon the attitude of distrust and resignation and try to make them those who are engaged in the service of love, share their wisdom and are witnesses of hope, deserve attention: let grandparents be active again in families, in the Church and in society. When it comes to families, let grandparents continue to be witnesses of unity in them, values based on fidelity to the one love that breeds faith and joy in life (Benedict XVI 2008).

\section{For further discussion...}

In conclusion, the topic of the religiosity of older adults during Covid-19 based on the example of the activities of the Catholic Church - draws special attention to four aspects related to the social teaching of the Church.

- The sociological and theological reflection indicates that the size and nature of the crisis should be properly assessed, that is, a pandemic is not an apocalypse but a temporal phenomenon, the effects of which can be limited by decisive, appropriate and effective action. It is an experience that should make us reflect and seek a responsible life in security and freedom.

- The crisis gives direction to our ethos, that is, all economic, social and medical activities are intended to emphasize the importance of human dignity. This is the stage of introducing global solidarity, which takes place first in our immediate environment and results in Christians from faith in God, and is carried out within the framework of the most important commandment - love of God and neighbour.

- The Church as a community is to accompany all manifestations of the experience of sickness, suffering, sorrow, care and fears that affect individuals and their families in this pandemic time, as well as to comfort, strengthen, support people and remind people of the hope of eternal life, which does not negate the earthly, but illuminates it with its light. 
- Finally, service to others is also necessary. By undertaking charity work, the Church is there where general needs are met, in health care, in nursing the sick, in work with children and youth, in the field of education. This is done depending on the possibilities and social needs. Many of these actions are now carried out through the media (Söding 2020: 127-129).

The principles of social life, i.e., the principle of the common good, solidarity and subsidiarity, to which the Catholic social teaching calls, are implemented in the pandemic era, going far beyond the boundaries of the Church, embracing spiritual and charitable help every person and above all older adults. It is worth citing the reflection of one of the Internet users who wrote that

mankind got exactly the disease it needed. We stopped respecting health, so the disease made us realize that we should care more about it. We stopped being in families, so the disease locked us in our homes to remind us and teach us how to function with loved ones. We stopped respecting the older and the sick, so the disease exposed them the most so that we would remember how vulnerable they were. We have stopped appreciating health workers and pharmacists, so the disease has allowed us to see how essential they are. We stopped respecting teachers, so the disease closed our schools so that parents could try to teach their children themselves. We paid a lot of attention to our appearance and comparing ourselves, so the disease covered our faces to make us understand that beauty is not in appearance. The pandemic took a lot from us, but at the same time gave us the opportunity to learn and understand what is most important in life.

(Przygoda 2020: 124-125)

\section{References}

Adamski F., Socjologia religii. Wprowadzenie, in: Socjologia religii, (red.) F. Adamski, Petrus, Kraków 2011, pp. 5-7.

Augustin G., Świadczyć o życiu w śmiertelnym świecie, in: Odkrywanie wspólnoty. Wiara w czasach pandemii koronawirusa, (red.) W. Kasper, G. Augustin, Kraków 2020, pp. 61-98.

Benedict XVI, Dziadkowie sa cennym skarbem każdej rodziny, https://opoka.org.pl/ biblioteka/W/WP/benedykt_xvi/przemowienia/dziadkowie_05042008.html

Dziedzic J., Kościół wobec starości. Perspektywa pastoralnoteologiczna, Polonia Sacra 19 (2015) 1 (38).

Dziedzic J., Przeszkody i szanse w poszukiwaniu godnej starości, in: Odnaleźć wykluczonych. Wsparcie terapeutyczno-duszpasterskie pacjentów szpitala Specjalistycznego im. dr. Józefa Babińskiego w Krakowie, (red.) J. Dziedzic, J. Klimek, Wyd. Szpital Specjalistyczny im. dr. Józefa Babińskiego SP ZOZ w Krakowie, Kraków 2014, pp. 213-230. 
Francis, Homilia poprzedzająca błogosławieństwo Urbi et Orbi, https://papiez.wiara. pl/doc/6235496.Franciszek-podczas-modlitwy-o-ustanie-pandemii (27.01.2021).

Gagat-Matuła A., M. Myśliwiec, Wychowanie do starości, in: Starzenie się z godnościa, (red.) S. Steuden, M. Stanowska, K. Janowski, KUL, Lublin 2011, pp. 291-315.

Główny Urząd Statystyczny, Życie religijne w Polsce. Wyniki badania spójności społecznej 2018, https://stat.gov.pl/obszary-tematyczne/inne-opracowania/wyznaniareligijne/zycie-religijne-w-polsce-wyniki-badania-spojnosci-spolecznej-2018,8, 1.html (15.12.2020).

Halik T., Pandemia jako doświadczenie ekumeniczne, in: Odkrywanie wspólnoty. Wiara $w$ czasach pandemii koronawirusa, in: Odkrywanie wspólnoty. Wiara $w$ czasach pandemii koronawirusa, (red.) W. Kasper, G. Augustin, WAM, Kraków 2020, pp. 131-164.

Handerek Katarzyna, Mieszkałam w sekcie, https://www.polskieradio.p1/9/325/ Artykul/2626431,Uwaga-Koronawirus-sprzyja-sektom (27.01.2021).

Ilnicka R., Wychowanie do starości, Edukacja i Dialog 4 (2006), pp. 69-72.

John Paul II, List do moich Braci i Sióstr - ludzi w podeszlym wieku, 16. http:// www.vatican.va/content/john-paul-ii/pl/letters/1999/documents/hf_jpii_let_01101999_elderly.html

Koch K., Koronawirus widziany oczyma wiary, in: Odkrywanie wspólnoty. Wiara w czasach pandemii koronawirusa, (red.) W. Kasper, G. Augustin, WAM, Kraków 2020, pp. 43-60.

Lipiec D., Rozmowa duszpasterska $w$ dobie pandemii, in: Duszpasterstwo $w$ czasie pandemii, Instytut Gość Media, Katowice 2020, pp. 175-183.

Nota Komisji Nauki Wiary Konferencji Episkopatu Polski w zwiazku z pandemia koronawirusa. „Jezus żyje i chce, abyś żyl”, in: Duszpasterstwo w czasie pandemii, Instytut Gość Media, Katowice 2020.

Przygoda W., Wartość Kościoła Domowego w dobie pandemii, in: Duszpasterstwo w czasie pandemii, Instytut Gość Media, Katowice 2020, pp. 119-125.

Skworc W., Słowo wstępne abp. Wiktora Skworca, przewodniczacego Komisji Duszpasterstwa KEP, in: Duszpasterstwo w czasie pandemii, Instytut Gość Media, Katowice 2020, pp. 5-11.

Söding T., Dystans i kontakt, in: Odkrywanie wspólnoty. Wiara w czasach pandemii koronawirusa, (red.) W. Kasper, G. Augustin, WAM, Kraków 2020, pp. 99-130.

Stańko Katarzyna, "Le Monde": epidemia Covid-19 zdemaskowała działalność sekty Shincheonji $z$ Korei Ptd., https://forsal.pl/artykuly/1460145,le-mondeepidemia-covid-19-zdemaskowala-dzialalnosc-sekty-shincheonji-z-korei-pld. html (27.01.2021)

Ziębińska B., Uniwersytety Trzeciego Wieku jako instytucje przeciwdziałajace marginalizacji osób starszych, WN Śląsk, Katowice 2010.

Zwoliński A., Od powietrza... Ludzie w czas zarazy, Petrus, Kraków 2020. https:// ekai.pl/sekta-nauki-o-szczesciu-w-czasie-pandemii-koronawirusa/ (27.01.2021). 